\title{
Az OECD gLOBÁlis POLITIKÁJÁNAK ELŐNYEI ÉS HÁTRÁNYAI
}

\author{
POGÁTSA ZOLTÁN \\ Soproni Egyetem \\ Beérkezett: 2021. szeptember 10., elfogadva: 2021. október 26.
}

A tanulmány célja annak vizsgálata, hogy az elmúlt évtizedekben az OECD milyen szerepet vitt a globális és a nemzeti szintű szocioökonómiai modellek alakításában. Vizsgáljuk befolyásának erejét, illetve azt is természetesen, hogy milyen irányba mozdította a folyamatokat. Ehhez egyrészt visszamegyünk időben a kezdetekhez és elemezzük a szervezet szerepének alakulását, másrészt pedig összehasonlítjuk más meghatározó nemzetközi szervezetekkel.

Kulcsszavak: OECD, tudásgazdaságtan, humántőke, neoliberalizmus

This study aims to examine the global role played by the OECD as an organisation in influencing socio-economic models around the world, as well as in individual nation states, with special attention to the concept of the 'knowledge economy'. In order to carry out this assessment, we return to the precursors of this organisation after the World War Two. The role played by the OECD is then discussed across time, and in comparison to other major international economic institutions, such as the IMF, the World Bank and the European Union.

Keywords: OECD, knowledge economy, human capital, neoliberalism

\footnotetext{
Telen írás célja annak vizsgálata, hogy az elmúlt évtizedekben az OECD milyen szerepet vitt a globális és a nemzeti szintü szocioökonómiai modellek alakításában. ${ }^{1}$ Vizsgáljuk befolyásának erejét, illetve azt is természetesen, hogy milyen irányba mozdította a folyamatokat. Ehhez egyrészt visszamegyünk időben a kezdetekhez és elemezzük a szervezet szerepének alakulását, másrészt pedig összehasonlítjuk más meghatározó nemzetközi szervezetekkel.
}

Levelező szerző: Pogátsa Zoltán, Soproni Egyetem, 9400 Sopron, Erzsébet u. 9.

E-mail:pogatsa@gmail.com

1 Köszönöm Halász Gábor és Polónyi István hasznos javaslatait az elemzéshez. 


\section{A kezdetek: európai szervezet amerikai célokkal}

Az európai társadalmak még a második világháborút követően is kevésbé egyértelmű lelkesedéssel fogadták a modernitás új technológiáit, mint az amerikai társadalom. Miközben persze Európában is megvoltak a „haladás” lelkes hívei, sokan az elembertelenedést látták benne, amely egyben kommodifikálja, kizsákmányolja és periferizálja az embert, a helyébe a gépet állítva. Aldous Huxley 1932-es Szép új világja csak a legismertebb megnyilvánulása ennek az aggodalomnak, számtalan további regény és film vetítette előre ezt a negatív utópiát. A szociáldemokrácia és a jóléti államok csúcskorszakában ráadásul még attól is joggal tarthattak, hogy a technológiai haladás a gyakorlatban a gépesítésen keresztül a növekvő munkanélküliséget, a stagnáló béreket és a magasabb profitrátát hozza el.

$\mathrm{A} z$ OECD eredete ismert módon a Marshall-tervhez kötődik. A második világháború utáni újjáépítés volt az a kontextus, amelyben egy közös európai fejlesztési szervezet gondolata testet öltött. A Marshall-tervhez máig hatóan számos illúzió kötődik, leginkább az, hogy ez egyfajta önzetlen amerikai segítség volt a háború által lerombolt európai gazdaságok újraindítására. Ahogy (Varoufakis-Theocarakis-Halevi 2011) bemutatják, a valóság ennél bonyolultabb. A Marshall-terv célja az újjáépítés mellett az volt, hogy a támogatott országokban amerikai cégek számára keresletet, megrendeléseket teremtsenek. Azaz a mai kínai „egy öv, egy út” programhoz hasonló elgondoláson alapult, csak jelentősen kisebb léptékben. Ráadásul a támogatott országok többsége masszív katonai megrendelője is volt az Egyesült Államok hadiipari cégeinek, azaz az összgazdasági nettó az USA cégei számára jelentősen pozitív volt. Természetesen tagadhatatlan, hogy a Marshall-terv az újjáépítésben is szerepet játszott, valamint egyben platformot szolgáltatott az eltérő amerikai és európai gazdaságfilozófiák interakciójának is.

A Marshall-tervből kinövő Organisation for European Economic Cooperation (1948) hamar magára vállalta a feladatot, hogy megváltoztassa a növekedéssel és a technológiai „haladással” kapcsolatos európai attitűdöket. Ezen belül különösen a szervezet által létrehozott European Productivity Agency (EPA) ügyévé vált ez a kérdés (Bürgi 2019), amelyet 1953 májusában hoztak létre. Az ügynökség rögtön megkapta az OEEC költségvetésének 40\%-át, ami jelzi, hogy az első pillanattól jelentős szerepet szántak neki (Boel 2003: 97). A szervezetről egyedüliként monográfiát író dán szociológus, Boel kiemeli, hogy a termelékenységi paradigma alapvetőn „amerikai eszmékre alapozott, amerikai pénzbooll”. ${ }^{2} \mathrm{Az}$ EPA fó támogatója ráadásul az amerikai kormány mellett a Ford Alapítvány volt, azaz a magángazdasági forrásait is költötték rá, ennek ideológiai implikációival. A technokrataként pozícionált ideológiai alap pedig alapvetőn az elosztási kérdéseket próbálta meg áttranszformálni növekedési kérdéssé. Ezzel egyrészt erősítette a gazdasági növekedés szükségességének kultuszát, amely Európában ekkor messze nem volt olyan erőteljes, mint az Egyesült Államokban. Az öreg kontinensen még nagyon sokan stacioner gazdasági kibocsátásban gondolkodtak, természetesen még nem a mai posztindusztriális fenntart-

Slobodian (2018: 159) viszont rámutat, hogy mekkora ellentmondás áll fenn az USA szabadpiaci ideológiája, illetve a között a tény között, hogy a Marshall-segély befogadására az USA a kedvezményezett országokat többéves terv elkészítésére kötelezte. 
hatósági aggodalmak miatt, hanem hagyományos megközelítésből. Az a logikai láncolat, hogy a termelékenység növekedéshez vezet, ami pedig mindenkinek megemeli az életszínvonalát, terjedő ideológia volt még csak ekkortájt. Ez még messze a klímaváltozással, fajpusztulással, kimerülő anyagfelhasználással és kritikus környezeti terheléssel kapcsolatos tapasztalatok előtti korszak, a gazdasági növekedés globális korlátai a modernitás zenitjén még nem voltak a térképen sem. Az amerikai növekedési megszállottság egyik forrása a Nagy Gazdasági Világválság keserü tapasztalata volt. Ehhez kapcsolódik a GDP mutató megalkotása is Simon Kuznets által, amely lehetővé tette a növekedés kvantifikálását. Kuznets ismert módon hangsúlyozta, hogy a GDP kibocsátási és nem életszínvonal-mutató, és ekként is lenne helyes használni. Figyelmeztetését azonban azonnal ignorálták, és a mutató azóta is többnyire fejlettségi vagy életszínvonal-mutatóként szerepel a közgazdasági irodalomban és a médiában. A technológiai-növekedési fókuszt aztán tovább élesítette a két hidegháborús nagyhatalom közti vetélkedés, melynek szimbolikus fordulópontja volt a szputnyik 1957-es fellövése, amely rámutatott az Egyesült Államok technológiai előnyének szükülésére.

A termelékenységi narratívának egyben pacifikáló hatást is szántak. Semlegesíteni kívánta az osztálykonfliktust, a helyébe a bőség versus pazarlás dichotómiát állítva. A mából visszanézve már tudjuk, hogy a növekedés csak a jóléti állam korszakában biztosított mindenkinek életszínvonal-bővülést, az azt követő neoliberális korszakban már nem (Piketty 2017, 2020; Saez-Zucman 2019). Amikor az OEEC átalakult OECD-vé 1961-ben, magát az EPA-t megszüntették, ám a szerepköre nemcsak fennmaradt, de tovább is bővült.

\section{A hatvanas évek gazdaságfilozófiai újítása: a „humán tőke” és az „oktatásgazdaságtan”}

A hatvanas évek az oktatásgazdaságtan fogalmának jegyében telt. A közgazdaságtudomány fejlődés-gazdaságtani irányzata megalkotta azt a meghatározó alapmodelljét, amely mind a mai napig a neoklasszikus fejldődéselmélet központi eleme. Ez a híres Solow-modell, amely Robert Solow, ma már Nobel-díjas amerikai közgazdászról került elnevezésre (Solow 1956). Lényege, hogy egy gazdaság fejlődhet a beruházott tőke emelésével, a megnövelt foglalkoztatással, ${ }^{3}$ de létezik egy harmadik tényező is, amelyet a tőke és a foglalkoztatottak száma önmagában nem tud megmagyarázni. Szokás ezt solow-i reziduumnak is nevezni, azaz a „maradéknak”, a „minden másnak”. Itt alapvetően puha tényezők vannak, amelyre lehet úgy gondolni, mint a technológia fokára vagy a társadalom képzettségi szintjére is. Valamint számos további tényezőre. Az intézményi közgazdaságtan például a tág értelemben vett, azaz formális és informális intézmények, szokások, attitűdök egészére fókuszál. Jelentős komponense ennek például a korrupció foka.

Bárhogy is gondolunk a solow-i reziduumra, annak mindenképpen meghatározó kapcsolódása van az össztársadalmi tudáshoz. A technológia nem önmagában álló, kizárólag tárgyiasult valami, hiszen az múltbéli tudományos eredményeken nyugszik, azt meg

Természetesen már a megnövelt tőkeállomány és foglalkoztatás is feltételezi, hogy a tőkejavak működtetésére képes, azaz megfelelően képzett foglalkoztatotti állomány áll rendelkezésre. 
kell tervezni, illetve képzett személyzetnek múködtetnie kell. Azaz egyszerre feltételez magas szintű tudást és hétköznapi tudást (együttműködés, menedzsment, információáramlás, válságkezelés stb.). Végső soron tehát a solow-i reziduum egy adott társadalom nagyon széles értelemben vett tudásának szintje.

Ez pedig jó közös alapot adott az oktatási szakemberek és a közgazdászok egyfajta kiegyezésének. Azért indokolt itt a „kiegyezés” kifejezés félig-meddig komolyan, mert korábban a két csoport viszonya inkább antagonisztikusnak volt mondható. A fejlődésgazdaságtani gondolkodással azonban megszületett a „tudástőke” kifejezés, amely a tudást termelési tényezők, a tőke és a munka mellé rendeli. (Illetve az ideológiai vakfolt miatt ritkábban emlegetett föld mellé, amely a tőkéből szerzett profittal szemben a földből - ingatlanból, illetve bármely természetes vagy mesterséges monopóliumból - szerzett járadék alapja.) A „tudástőke”, a „humántőke” ilyen formában bekerült a nyugati világ közgazdaságtani gondolkodásának középpontjába. Ez pedig nemcsak az oktatási szakértők és a közgazdászok között teremtette meg a kompromisszum lehetőségét, hanem a különböző politikai irányzatok is megegyezhettek abban, hogy az oktatásra óriási szükség van, ha fejlődést szeretnénk indukálni és fenntartani.

Ennek a típusú gondolkodásnak a megtestesülése lett az „oktatásgazdaságtan” mint önálló diszciplína. Ennek a megközelítésnek a lényege, hogy az oktatásra mint megtérülő beruházása gondolunk. Az OECD a hatvanas években már egyértelmüen az élére kívánt állni ennek a törekvésnek. Az oktatásgazdaságtan beruházásalapú felfogása feltételezi, hogy az oktatás különböző aspektusait kvantifikálhatóvá tesszük - a közgazdaságtanban amúgy is igen erős az elfogultság a mérhetőség mellett. Pénzmennyiséggel kifejezhető az oktatási beruházás. A végeredmény, a gazdaság növekedése szintén kifejezhető pénzmennyiséggel a GDP mutató megalkotása révén. A foglalkoztatás növelése szintén kifejezhető emberfőben. A pénzügyi inputok és ezen makrogazdasági outputok közé pedig beilleszthetők magának az oktatási rendszernek a különböző output indikátorai, ráadásul amennyiben lehet, időben és térben összehasonlítható módon. Közismert módon ebben világszinten is vezető szerepet játszott az OECD.

A törésvonalak csak később, a neoliberalizmus (Blyth 2002; Duménil-Lévy 2004; Mirowski 2015) nyolcvanas évekbeli kiterjedésével váltak láthatóvá. A különböző felek ugyanis egészen mást értettek humántőke alatt. Világossá vált, hogy a piaci fundamentalisták számára nem többről van szó, mint hogy az oktatási rendszer szolgálja ki „a piac igényeit", és semmi többet (Mirowski 2011). Ez a gyakorlatban azt jelenti, hogy nem szempont sem a társadalmi mobilitás biztosítása, sem a kritikai megközelítés megtanítása, sem a demokráciához szükséges alaptudás megadása, a magas kultúra továbbvitele és széles körü terjesztése. A szüken vett cél az, hogy a piac különböző szegmenseiben biztosítva legyen a munkások sokasága, mindenki esetében a megfelelő képzettségi szinten. Foucault (2010: 224) egyenesen arról beszélt a Collège de France-ban tartott előadássorozatában, hogy a humántőke perspektíva a munkásokat dehumanizálja, a gépekkel egy szintre fokozza le. Ralf Dahrendorf (OECD 1961:20) is aggodalmát fejezte ki, hogy a képességek és az anyagi értékek megteremtése csupán eszköz kellene legyen az egyéni polgár életének kiteljesítéséhez.

A szociáldemokraták ehhez képest az oktatástól a társadalmi mobilitás megteremtését és fenntartását várták, a nemek közötti esélyegyenlőséget, a magaskultúra elterjesztésének lehetőségét, illetve a piaci versenyhez szükséges társadalmi tőke általános biztosítását. A megtérülő oktatási beruházás narratíváját elfogadhatónak vélték, egyfajta trójai 
falónak, melynek segítségével a konzervatív harmadik világbeli országokban elérhetővé válik az általános és ingyenes oktatási rendszerek elterjedése, a tudományos világnézettel együtt. A skandináv szociáldemokraták még az életen át tartó tanulás szempontjait is behozták a képbe, kezdetben „recurrent education” (vissza-visszatérő tanulás) címszó alatt (Rubenson 1994). Az ezzel járó „rugalmasság” a szociáldemokrata megközelítésben az esélyteremtés garanciája volt, mellyel a skandináv aktív munkapiaci modellben (lásd Rehn-Meidner-modell) újabb esélyt kínáltak államilag finanszírozott átképzésekkel azoknak, akiknek a képességei a technológiai fejlődés körülményei között kiárazódtak. Az OECD szívesen vált ennek a megközelítésnek a propagálójává, és az később az Európai Uniónak is hivatalosan vállalt filozófiájává vált az Európai Szociális Alap keretei közt. Az eredetileg "flexicurity”-nek címkézett megközelítésnek azonban Skandinávián kívül a „flexibility” (rugalmasság) előtagja a neoliberális gazdasági kontextusban gyorsabban terjedt, mint a „security” (biztonság) utótag. Az életen át tartó tanulás fogalma az idők során az újabb és újabb esélyteremtés helyett a folyamatos létbizonytalanság, a könnyü leépítés, az állandó újratanulási kényszer, az elidegenedés és gyökértelenség szinonimájává vált a neoliberális fogalmi térben. Ráadásul az oktatás tervezésének igénye is megkopott, miután a felsőoktatás hatalmasra növelése a fejlett országokban ennek a szintnek a megduzzasztásához vezetett, ezen keresztül pedig az egyetemi diploma, sőt, egy idő után a PhD-fokozat elinflálódásához is (Polónyi-Tímár 2001). Mindez pedig visszaható módon megkérdőjelezte az oktatási rendszerek tervezhetőségét is, ami viszont ismét csak a tévesen hatékonyabbnak tételezett piacosított oktatás igényét erősítette.

A mából nézve világosan látszik, hogy a humántőke narratívának a neoliberalizmus évtizedeiben inkább a piaci fundamentalista olvasata vált valósággá. Újabb ütközési pontként jelentkezett ráadásul a növekedési korlátok kérdése is időközben.

\section{Az OECD szerepe: technokrata soft power}

1961-es megalakulásával az OECD radikálisan kilépett az elődszervezet OEEC kereteiből mind földrajzilag, mind tematikusan. Az OECD immáron a világgazdaság fejlődéséhez és a világkereskedelem bővüléséhez kívánt hozzájárulni alapító okiratának legelső cikkelye szerint. Tagsága nemcsak annyiban bővült, hogy az európai országok mellett az Egyesült Államok és Kanada is belépett, hanem egy idő után a fejlett világ más részeiről is taggá váltak országok. 2019-re már 36 tagja volt, melyek bár globális összehasonlításban relatíve fejlettnek voltak mondhatóak, ám köztük szintén jelentős különbségek mutatkoztak. Bár egytől egyig mind kapitalista gazdaságok, ám a kapitalizmus válfajai kutatási program (Boble-Greskovits 2012; Hall-Soskice 2001; Johnson 1982; Nölke-Vliegenthart 2009) klasszifikációinak megfelelően meglehetősen különböző kapitalizmusvariánsokat testesítettek meg. Vannak köztük skandináv és nyugat-európai jóléti államok, a mediterrán modell országai, angolszász típusú liberális piacigazdaságok, távol-keleti fejlesztőállamok, illetve kelet-európai müködőtőke-függő versenyállamok.

Ráadásul az OECD együttműködést kezdeményezett a tagságán kívüli országokkal is. Ennek elsődleges formája a gazdasági kérdésekre koncentrál, de például létrehozta a Development Assistance Committee-t is, amely berlini, mexikóvárosi, tokiói és washing- 
toni székhelyeivel a világbékéhez is hozzá kíván járulni. Ezenfelül tudatosan keresi a kapcsolatot a nem kormányzati szervezetekkel, illetve a kormányközi szervezetekkel.

$\mathrm{A} z$ immáron globális szerepet vállaló OECD fenntartotta a humántőke és az oktatásgazdaságtan technokrata nyelvezetén keresztül a pozitív ráhatást a kormányzatokra (Armingeon-Beyeler 2004; Ydesen 2019). Az oktatásra fókuszáló gazdasági filozófia globális irányításában az OECD kulcsszerepet a Programme for International Student Assessment (PISA) tesztek megalkotásával vívott ki magának.

A tesztet az 1968-ban létrehozott Centre for Educational Research and Innovation (CERI) szűkebb körű országjelentései előzték meg. A PISA-folyamat maga 1988-ban kezdődött egy előkészítő fázissal, amelyet az indikátorok és a módszertan kialakítása követett. Az első teszteredmények 2001-ben jelentek meg, akkor 32 ország vett részt benne. 2015-ben már 72 ország. A PISA-tesztek nem egyszerűen összehasonlíthatóságuk miatt váltak rendkívül befolyásossá. Hasonló nemzetközi teszteket végzett már korábban is, például az International Organisation for the Evaluation of Educational Achievements (IEA). A PISA program kulcsfontosságú elemei a tesztekhez kapcsolódó országjelentések, összehasonlító elemzések és szakmai javaslatokat tartalmazó írásos anyagok. Mint ismert, ezek nem kötelező érvényűek, hanem a puha kormányzás eszközeivel élnek: javaslatokat tesznek, benchmarkokat állítanak fel, problémákat tárnak fel. Nem elhanyagolható a "naming and shaming” hatás, azaz hogy az érintett országok sajtója felkapja, ha az oktatási rendszer elmaradást mutat a világ többi részéhez képest. Erős áthallások vannak itt a nemzeteket megversenyeztető, a nemzeti büszkeségre építő különböző más nemzetközi eseményekkel, mindenekelőtt az olimpiákkal. Ez természetesen egyszerre káros annyiban, hogy erősíti a nacionalizmusokat, ám ugyanakkor kétségtelenül hatásos a szakpolitikák előmozdítása szempontjából. Különösen demokratikus rendszerekben lehet komoly visszacsatoló hatása kormányzatok és politikai pártok választói megítélésén keresztül, de számos példánk van arra is, hogy ennek a puha késztetésnek nem demokratikus országokban is befolyása van. A két legismertebb példa talán Szingapúr és Kína.

A nemzetközi összehasonlító indexeket sokszor éri kritika. Ennek több különböző formája van. Egyesek szerint maga a kvantifikálhatóság, az indexálás fókusz káros. Mások azt vetik fel, hogy mindenfajta mérésnek kulturális elfogultságai vannak. Mindezekben a kritikáknak nyilvánvalóan van bizonyos szintű érvényességük. Ugyanakkor tegyük fel a kérdést: mi lenne a helyzet ezen indexek hiányában? A nemzeti szintü belpolitikai harcokból ismert, hogy az egyes politikai irányzatok képesek alternatív valóságok felvázolására és fenntartására, melyeket elkötelezett híveik kitartóan propagálnak. Nemzetközileg elfogadott, szakmailag objektív mérőszámok hiányában egyszerüen képtelenség lenne eldönteni, hogy melyik alternatív politikai narratíva, helyzetleírás áll közelebb a valósághoz. Ez pedig minden kétséget kizárólag a demokrácia kiüresedéséhez vezetne.

Ebből a szempontból elmondható, hogy más nemzetközi gazdasági szervezetekkel szemben az OECD kifejezetten pozitív szerepet játszott. A Világbank és az IMF aktívan részt vett a neoliberális világrend kiépítésében és fenntartásában a Washingtoni Konszenzusra építő „stabilizációs programok” erőltetésével (Stiglitz 1994). Az Európai Unió valamivel komplikáltabb eset, mivel egyszerre vannak jelen benne a progresszív és a neoliberális elemek, bár elsősorban a közösségi intézmények gyengesége miatt inkább az utóbbiak domináltak (Galbraith 2016; Stiglitz 2016; Tooze 2019; Varoufakis 2017). 
Ezek a programok tipikusan a megszorítások logikájára épültek, és a humántőke képző alrendszerek (oktatás, egészségügy, szociálpolitika) finanszírozásának olyan mértékü csökkentését eredményezték, amely hátráltatta a gazdasági fejlődést, a társadalmi mobilitást. Ezzel szemben a kiadási oldalon tipikusan nem kezelte az aluladóztatás és az adóelkerülés problémáit, különösen az államot foglyul ejtő oligarchák esetében. A megszorítások ezen logikája az akadémiai elemzések szerint is káros volt (lásd erről Blyth [2015] összefoglalóját), sőt, néha még a nemzetközi pénzügyi intézmények saját háttérkutatóintézményei is kritikusak voltak azzal kapcsolatosan (Ostry-Loungani-Furceri 2016). Ennek ellenére a neoliberális gazdaság- és társadalompolitika kikényszerítése folytatódott. A Világbank, az IMF és az EU csak a 2020-as Covid-válság idején váltott, és immáron a keynesiánus keresletnövelő politikával kívánta a válságot kezelni (Tooze 2021).

$\mathrm{A} z$ OECD ezzel szemben a maga puha eszközeivel mindvégig a progresszív folyamatokat segítette elő. Példa erre a PISA-hoz kötődő elemzések azon része, ahol az eredményeket az oktatási rendszer társadalmi mobilitást elősegítő szerepe szempontjából elemzik a szakértők. Ez egyszerre foglal magába - nem különösen explicit módon - osztályalapú elemzést, társadalmi nem alapú elemzést, illetve területi alapú elemzést. Ráadásul az OECD anyagaiban folyamatosan a „skill” szó legtágabb értelmezése szerepel, nem a szüken vett piaci értelmezés. Példa erre az OECD „társadalmi és emocionális képességekkel" kapcsolatos jelentéssorozata (OECD 2021). Ráadásul az OECD-nek időközben létrejött a kifejezetten piaci képességekre koncentráló nemzetközi összehasonlító vizsgálata, amely elkülönül a jobban ismert PISA-felméréstől, és a már munkában állók hasonló készségeit, képességeit méri. Ez a Programme for the International Assessment of Adult Competencies (PIAAC).

$\mathrm{A} z$ OECD progresszív szerepére további példa a szervezet adóelkerülés elleni küzdelme. A rendkívül alacsony adókkal más országok adóalapját elszipkázó offshore területek a nem adóparadicsom országokban az adóelkerülés első számú eszközei a nagyvállalatok és az oligarchák esetében. Az OECD jelentős erőfeszítéseket tett ezen adóelkerülés ellen, igazságosabb adóelosztási alapelveket támogatva az országok között. Szintén progresszív alapelveket fogalmaztak meg a transzferárazás gyakorlata ellen. Ez utóbbi azt jelenti, hogy a világkereskedelem nagyobbik részét kitevő, transznacionális cégeken belüli és nem azok közötti kereskedelem esetében az anyacég olyan eladási-vételi árakat állapíthat meg, amelyek a nyereséget a magasabb kulcsokkal adóztató országból az alacsonyabb kulcsokkal adóztató ország felé áramoltatják - papíron. Ez pedig jelentős mértékben csökkenti az egész vállalatcsoport teljes adóztatását. A transzferárazásban szintén komoly szerepet visznek a rendkívül alacsony, illetve egyes esetekben kifejezetten nulla adókulcsokkal operáló offshore területek.

$\mathrm{A} z$ offshore adóelkerüléssel foglalkozó vezető akadémiai közgazdászok (Zucman 2016) és elismert nemzetközi NGO-k (Tax Justice Network) egyaránt kritizálták azt, hogy az OECD következmények nélküli egyezmények nyomán levett offshore listájáról olyan országokat, amelyek továbbra is jelentős adóparadicsomi tevékenységet folytatnak, és többségében továbbra sem szolgáltatnak érdemi információkat betéteseik kilétéről. Ennek ellenére ezen kritikusok is úgy nyilatkoztak, hogy az OECD még mindig többet tett az offshore adóelkerülés ellen, mint például az Európai Unió, amely utóbbi szervezetnek egyébként jelentősebb jogosítványai lennének a fellépésre. Ráadásul azt is érdemes megemlíteni, hogy a Joe Biden amerikai elnök által szorgalmazott - és valószínűséggel 
végre nemzetközileg elfogadottá váló - globális minimáladó koncepciója is az OECD eredeti elképzelésein alapul.

\section{$\mathrm{A} z$ OECD globális szerepe}

Összefoglalásként elmondható, hogy az OECD csak fokozatosan érte el, hogy globális szereplővé váljon. A második világháború utáni évtizedekben európai intézményként működött, és csak évtizedekkel később nyitott, akkor is a fejlettebb országok irányába. Mára azonban a szüken vett tagságát is meghaladó, immáron valódi globális hatása van a szervezetnek.

Ennek a hatásnak a jellegzetessége, hogy puha eszközökkel képes a kormányzatok szakpolitikáit befolyásolni, ezen keresztül pedig az egyes országok szocioökonómiai modelljeire hatni. Ez az OECD-t élesen szembeállítja a többi ismert nemzetközi szervezettel, az IMF-el, a Világbankkal, illetve még az Európai Unióval is. Ezek ugyanis kemény eszközökkel (hitelnyújtás, stabilizációs programok, az Unió esetében kiterjedt szupranacionális jogrendszer) képesek közvetlenül, akár kényszerítő erővel is hatni.

De különbség mutatkozik tartalmi kérdésekben is. Míg a többi említett nemzetközi pénzügyi intézmény a neoliberális társadalomfilozófia kikényszerítőjeként lépett fel globálisan évtizedeken keresztül, addig az OECD-röl elmondható, hogy ennek oktatásgazdaságtani és adóigazságossági logikája végig szembement ezzel a világnézettel, még akkor is, hogyha ezt a szervezet korlátozott mandátuma miatt csupán puha eszközökkel volt képes megfogalmazni. Az a cél ugyanis, hogy a világ minél több országa vegyen részt az OECD különböző nemzetközi összehasonlító vizsgálataiban, nem volt összeegyeztethető azzal, hogy az OECD nyíltan kritikát fogalmazzon meg azzal a neoliberális renddel szemben, amelynek a legtöbb együttműködő kormányzat aktív támogatója és kiépítője volt. Ezzel szemben a humán tőkére alapozó, technokrataként pozícionált narratíváján keresztül az OECD mégis képes volt érdemben ellentartani a kiépülö globális neoliberalizmusnak.

\section{IRODALOM}

Armingeon, K. \& Beyeler, M. (2004) The OECD and European Welfare States. Edward Elgar.

Bly тh, M. (2002) Great Transformations: Economic Ideas and Institutional Change in the Twentieth Century. Cambridge University Press.

Blyth, M. (2015) Austerity: The History of a Dangerous Idea. Illustrated edition. Oxford (NY), Oxford University Press.

Boel, B. (2003) The European Productivity Agency and Transatlantic Relations 1953-1961. Museum Tusculanum Press.

Boнle, D. \& Greskovits, B. (2012) Capitalist Diversity on Europe's Periphery. Cornell University Press.

Bürgi, R. (2019) Learning Productivity: The European Productivity Agency - An Educational Enterprise. In: The OECD's Historical Rise in Education - the Formation of a Global Governing Complex. Springer. pp. 17-37. 
Duménil, G. - Lévy D. (2004) Capital Resurgent: Roots of the Neoliberal Revolution. Cambridge, Harvard University Press.

Foucault, M. (2010) The Birth of Biopolitics: Lectures at the Collège de France, 1978-1979. First edition. New York, Picador.

Galbraith, J. K. (2016) Welcome to the Poisoned Chalice: The Destruction of Greece and the Future of Europe. Yale University Press.

Hall, P. A. \& Soskice, D. (2001, eds) Varieties of Capitalism: The Institutional Foundations of Comparative Advantage. Illustrated edition. Oxford (UK), Oxford University Press.

Johnson, Ch. (1982) MITI and the Japanese Miracle: The Growth of Industrial Policy, 1925-1975. 1st edition. Stanford University Press.

Mirowski, Pн. (2011) Science-Mart: Privatizing American Science by Pbilip Mirowski. Harvard University Press.

Mirowski, Рн. (2015) The Road from Mont Pèlerin: The Making of the Neoliberal thought Collective, with a New Preface. Harvard University Press.

Nölke, A. \& Vliegenthart, A. (2009) Enlarging the Varieties of Capitalism: The Emergence of Dependent Market Economies in East Central Europe. World Politics, Vol. 61. No. 4. pp. 670-702.

OECD (1961) Ability and Educational Opportunity. Paris, OECD.

OECD (2021) Beyond Academic Learning: First Results from the Survey of Social and Emotional Skills. Paris, OECD.

Ostry, J. D., Loungani, P. \& Furceri, D. (2016) Neoliberalism - Oversold? Finance and Development, June, https:/www.imf.org/external/pubs/ft/fandd/2016/06/ostry.htm [Letöltve: 2021.09.09.]

Piketty, TH. (2017) Capital in the Twenty-First Century. Reprint edition. Cambridge (MA); London, Belknap Press: An Imprint of Harvard University Press.

Piketty, Th. (2020) Capital and Ideology. Cambridge (MA) Belknap Press: An Imprint of Harvard University Press.

Polónyi I. \& TímÁr J. (2001) Tudásgyár vagy papírgyár? Budapest, Új Mandátum.

Rubenson, K. (1994) Recurrent Education in Sweden: A Moving Target. International Review of Education, Vol. 40. No. 3/5. pp. 245-56.

Saez, E. \& Zucman, G. (2019) The Triumph of Injustice: How the Rich Dodge Taxes and How to Make Them Pay. 1st edition. New York (NY), W. W. Norton \& Company.

Slobodian, Q. (2018) Globalists: The End of Empire and the Birth of Neoliberalism. Cambridge (MA), Harvard University Press.

Solow, R. (1956) A Contribution to the Theory of Economic Growth. Quarterly Journal of Economics, Vol. 70. No. 1.pp. 5-94.

Stiglitz, J. (1994) Globalisation and Its Discontents. 33492nd edition. New York (NY), W. W. Norton \& Company.

Stiglitz, J. (2016) The Euro: How a Common Currency Threatens the Future of Europe. New York (NY), W. W. Norton \& Company. https://www.amazon.com/Euro-Common-Currency-Threatens-Future-ebook/dp/B015TDWSCU/ref=sr_1_1?crid=2E6FGCYWBU89H\&dchild=1\&keywords $=$ joseph + stiglit $z+$ the + euro\&qid $=1631219276 \&$ sr $=8-1$ [Letöltve: 2021. 09. 09.]

Tooze, A. (2019) Crashed: How a Decade of Financial Crises Changed the World. Illustrated edition. New York, Penguin Books.

Tooze, A. (2021) Shutdown: How Covid Shook the World's Economy. New York City, Viking. 
Varoufakis, Y. (2017) Adults in the Room: My Battle with the European and American Deep Establishment. Illustrated edition. New York, Farrar, Straus and Giroux.

Varoufakis, Y., Theocarakis, N. \& Halevi, J. (2011) Modern Political Economics: Making Sense of the Post-2008 World. Routledge. https://www.amazon.com/Modern-Political-Economics-Making-Post-2008/dp/0415428882 [Letöltve: 2021. 05. 11.]

Ydesen, Ch. (2019, ed.) The OECD's Historical Rise in Education: The Formation of a Global Governing Complex. Palgrave Macmillan. https://www.palgrave.com/gp/book/ 9783030337988 [Letöltve: 2021. 09. 10.]

Zucman, G. (2016) The Hidden Wealth of Nations: The Scourge of Tax Havens. Illustrated edition. Chicago (IL), University of Chicago Press.

A cikk a Creative Commons Attribution 4.0 International License (https://creativecommons.org/licenses/ by/4.0/) feltételei szerint publikált Open Access közlemény, melynek szellemében a cikk bármilyen médiumban szabadon felhasználható, megosztható és újraközölhető, feltéve, hogy az eredeti szerző és a közlés helye, illetve a CC License linkje és az esetlegesen végrehajtott módosítások feltüntetésre kerülnek. (SID_1) 